The ribs of a serpent, which extend nearly throughout its whole length, are very much smaller near the neck and near the tail. At both these parts exuviation is much slower than where the larger ribs have play in the process. This rib action produced an automatic movement of the snake on the floor of its box, and across the folds of its companion, which kept as still as if it were dead. This involuntary movement of the reptile's body was almost imperceptible. All told, it might have been through two feet of linear space. But the exuviated skin was nearly six feet long. This movement seemed much greater than it really was. It was emerging from a tubular case, which was doubling upon itself for a while, the inner or unevolved part shortening as it moved forward with the body; the outer, or evolved part lengthening as it moved backward from the body. The cast-off skin is presented inside out, so that every scale is now seen on its under or concave side, and this is also true of the eye-scales. To all this there is one exception : the last scale of the tail is a hollow pyramidal or four-sided spike. This, for plain reasons, is not everted. When the shedding has reached this scale a sharp shake of the extremity is sufficient, and the uneverted spike is left inside of its everted skin. The entire process of exuviation, allowing five minutes for the part that I did not witness, took thirty-five minutes.

Let me add that in poor health a snake has a hard time in getting off its old coat. I could detail an instance wherein the process took three months. The old skin adhered stubbornly to the new one, and was only removed by friction and by tearing off mere bits at a time.

Freehold, New Jersey, U.S.

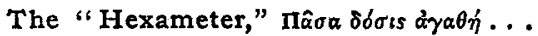

THERE is an obstacle in the way of regarding this passage (James i. I7) as a hexameter quoted by the Apostle from some poet, as the late lamented Prof. Clerk Maxwell is reported in Mr. Garnett's interesting notice of his life, work, and, not least, his character, to have suggested. The final syllable of $\delta \delta \sigma \omega s$ is short, as the accentuation of $\pi \rho \hat{\alpha} \xi \iota s$ and similar verbal

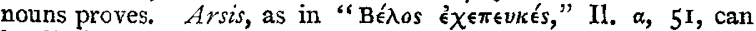
hardly be pleaded.

University Hall, W.C., November I7 J. J. WALKER

\section{THE SWEDISH NORTH-EAST PASSAGE} EXPEDITION ${ }^{1}$

DRING the wintering of the $V e g a$ large quantities of the bones of the whale were found on the beach. These at first were supposed to be the remains of whales that had been killed by the natives or by American whalers. On examination it was found that they must be sub-fossil. This was confirmed by the natives, who stated that no whale had driven on land in the memory of man. The remains were found to belong to four or five different species, of which Balena mysticetus, or a nearly allied type, was the most common.

Prof. Nordenskjöld investigated the formation of the strata of frozen earth several hundred feet thick which occur in Siberia as in Polar America. Along the coast of Siberia there is a stratum of water resting on the bottom of the sea which is several degrees below the freezingpoint, so that a flask of the comparatively fresh surface water, when sunk into this stratum, begins to freeze. Stuxberg observed that the trawl-net often froze fast to the bottom. This was accounted for by the freezing of the fresh water which the net carried down with it from the surface. Nordenskjöld thinks that the mud carried down by the rivers into the sea as it sinks to the bottom carries with it fresh water adhering to the minute particles, and that this fresh water, like that carried down by the net, freezes at the bottom, forming thus a frozen stratum, which increases year by year until it reaches an enormous thickness. He is of opinion that a portion of the earthy lavers of Siberia was formed in this way, although, he adds, he by no means considers this the only way in which such formations arose.

Along the whole coast, from the White Sea to Behring's Continued from p. 40.
Straits, no glacier was seen, During autumn the Siberian coast is nearly free of ice and snow. There are no mountains covered all the year round with snow, although some of them rise to a height of more than 2,000 feet. With one exception there were no rocks along the coast precipitous enough to be suitable breeding-places for seafowl, but a large number of these birds were seen during spring flying farther to the north.

During the voyage of the Vega from her winter quarters through Behring's Straits and farther south, Nordenskjöld searched for a tribe called Onkilon, said to be allied to the Eskimo, but without success. He found only reindeer-owning Tchuktches, and supposes that the name Onkilon, given by Wrangel to the old tribe inhabiting the coast and driven out by the Tchuktches, is probably related to the name Ankali, given by the reindeer-owning Tchuktches to the coast Tchuktches. Nordenskjöld states that English authors who refer Eskimo and Tchuktches to the same origin are mistaken. It was found that the inhabitants on the American side are pure Eskimo, with whom it was possible to carry on barter by means of the list of Eskimo words published in "Arctic Geography and Ethnology," London, I875; but that the language spoken by the Tchuktches, of which Lieut. Nordquist collected about I,00o words, is quite different, and probably allied to that of the Iranian races. On the other hand there is a complete correspondence between the household furniture of the Tchuktches and the Eskimo. It may be safely affirmed, he says, that these two neighbouring races have a greater number of identical articles in their tents than of common words in their languages.

The hills at Cape York on the American side were found to consist of crystalline schists without organic remains. Among the natives, who were Eskimo, there was a Tchuktch woman who said that Tchuktch tribes were settled on the American side between Point Barrow and Cape Prince of Wales. The Eskimo used, along with breechloaders, revolvers, and axes obtained from the Americans, bows and arrows, bone boat-hooks, and various stone implements. They were friendly and agreeable, and less given to brandy than the Tchuktches. There did not appear to be any chief among them. Complete equality prevailed, and the standing of the women did not appear to be inferior to that of the other sex. Among the stone implements were found arrow-heads and other articles of a species of nephrite so closely resembling the well-known nephrite from High Asia, that these implements were supposed to have actually come from that region.

A warm current, as in Europe, was found to flow along the north-western coast, and to create there a far milder climate than that which prevails on the Asiatic side. The limit of trees therefore lies a good way to the north of Behring's Straits, while the whole of the Tchuktch Peninsula appe $r$ s to be devoid of trees. This is the case also with the land along the coast at Port Clarence, but a short distance inland there were bushes two feet high, Vegetation was generally luxuriant, and a great number of species were identical with, or nearly allied to, those of the Scandinavian north, among others the Linnea. Notwithstanding the luxuriance of the vegetation, the land invertebrates were much poorer in species than in the north of Norway. Thus only from ten to twenty kinds of beetles could be found, principally Harpali and Staphylini, and of land and fresh-water mollusca only seven or eight species. The avifauna was also rather scanty, and the dredgings in the harbour at Port Clarence, on account of the unfavourable nature of the bottom, yielded only a small number of animal and vegetable species.

The Vega, crossing to the Asiatic side, anchored in Konyam Bay on July 28 . On the north shore of this Bay Dr. Kjellman added seventy species of flowering plants to the collection he had previously made. Here, too, were 